\title{
PRODUKSI DAN KARAKTERISTIK KACANG PINTO YANG DIBERI PUPUK KANDANG SAPI DAN MIKORIZA
}

\author{
Roni, N.G.K., N.N.C. Kusumawati, N.M. Witariadi, S.A. Lindawati dan N.W. Siti \\ Fakultas Peternakan, Universitas Udayana \\ Email: gustironi_fapetunud@yahoo.com
}

\begin{abstract}
ABSTRAK
Penelitian yang bertujuan untuk mengetahui produksi dan karakteristik kacang pinto (Arachis pintoi) yang diberi pupuk kandang sapi dan mikoriza serta kombinasinya dilakukan di rumah kaca menggunakan Rancangan Acak Lengkap pola factorial dua faktor. Faktor pertama adalah dosis pupuk kandang sapi (tanpa,10 ton/ha, 20 ton/ha dan 30 ton/ha). Faktor kedua adalah dosis mikoriza yaitu (tanpa, 10 g/pot, 20 g/pot dan $30 \mathrm{~g} /$ pot $)$, dengan tiga kali ulangan. Hasil penelitian menunjukkan bahwa terjadi pengaruh nyata $(\mathrm{P}<0,05)$ interaksi antara pupuk kandang sapi dan mikoriza pada peubah kolonisasi akar. Perlakuan pupuk kandang sapi berpengaruh nyata $(\mathrm{P}<0,05)$ pada peubah berat kering batang, berat kering daun, berat kering akar, berat kering tajuk, dan jumlah bintil akar. Perlakuan mikoriza berpengaruh nyata $(\mathrm{P}<0,05)$ pada peubah kolonisasi akar. Berdasarkan hasil penelitian dapat disimpulkan bahwa interaksi antara perlakuan pupuk hayati mikoriza dengan pupuk kandang sapi berpengaruh pada peubah kolonisasi akar, perlakuan pupuk kandang sapi dosis 20 ton/ha meningkatkan berat kering daun, batang, tajuk, akar dan jumlah bintil akar sama dengan dosis 30 ton/ha, dan perlakuan pupuk hayati mikoriza dosis $20 \mathrm{~g} /$ pot menghasilkan kolonisasi akar paling tinggi.
\end{abstract}

Kata kunci: Pupuk kandang sapi, mikoriza, kacang pinto (Arachis pintoi)

\section{PENDAHULUAN}

Dalam ransum ruminansia, porsi hijauan pakan mencapai $40-80 \%$ dari total bahan kering ransum atau sekitar $1,5-3 \%$ dari bobot hidup ternak. Secara nutrisi hijauan pakan merupakan sumber serat, bahkan hijauan pakan asal leguminosa menjadi suplementasi mineral dan protein murah bagi ternak ruminansia. Hijauan pakan berperan sebagai factor penggertak agar rumen sapi dapat berfungsi normal (Abdullah et al., 2005).

Kacang pinto (Arachis pintoi) merupakan salah satu tanaman pakan yang sangat disukai oleh ternak (palatable), memiliki nilai nutrisi yang tinggi dan memiliki beberapa fungsi yaitu sebagai pakan baik untuk ruminansia maupun non ruminansia, meningkatkan kesuburan tanah, mencegah erosi, serta menjadi tanaman hias (Ferguson, J.E. dan D.S. Loch, 1999). Kacang pinto juga dilaporkan memiliki produktivitas yang tinggi pada naungan 55\% dibandingkan tanpa naungan (Sirait, 2005). Panen hijauan pakan berarti pengambilan unsurunsur hara sehingga jumlahnya di dalam tanah menurun. Pemupukan merupakan salah satu cara untuk meningkatkan jumlah hara yang tersedia di dalam tanah, namun penggunaan pupuk kimia (anorganik) secara terus menerus dalam jangka waktu lama dapat menyebabkan tercemarnya kondisi lingkungan, juga dapat mengubah sifat-fisik tanah menjadi keras (Sugito, 1999). Pupuk hayati dan pupuk kandang adalah pupuk yang dapat memperbaiki sifatfisika, kimia, dan biologi tanah serta lingkungan, dengan demikian pupuk hayati dan pupuk kandang merupakan solusi yang sangat tepat. Salah satu Pupuk hayati yang sering digunakan adalah Cendawan Mikoriza Arbuskular (CMA).

Pupuk kandang sapi merupakan salah satu pupuk organic yaitu pupuk yang memiliki kandungan hara yang lengkap (Sumarsono dkk., 2005), dapat memperbaiki struktur tanah dan membantu perkembangan mikroorganisme tanah (Widjayanto dkk.,2001). Informasi tentang produktivitas kacang pinto yang diberi pupuk hayati dan pupuk kandang sapi masih sangat terbatas, sehingga berdasarkan kerangka pemikiran diatas, dengan dugaan adanya hubungan antara CMA dan pupuk organic maka penelitian dengan menggabungkan kedua faktor tersebut perlu dilakukan.

\section{METODE PENELITIAN}

\section{Rancangan Percobaan}

Penelitian ini menggunakan Rancangan Acak Lengkap pola factorial yang terdiri atas 2 faktor yaitu factor pertama adalah pupuk kandang sapi $\left(\mathrm{S}_{\mathrm{O}}=\right.$ tanpa pupuk kandang sapi, $S_{1}=$ pupuk kandang sapi1o ton/ ha, $\mathrm{S}_{2}=$ pupuk kandang sapi 20 ton/ha, dan $\mathrm{S}_{3}=$ pupuk kandang sapi 30 ton/ha), dan factor kedua 
adalah pupuk hayati mikoriza $\left(\mathrm{M}_{\mathrm{O}}=\right.$ tanpa mikoriza, $\mathrm{M}_{1}=$ mikoriza1o $\mathrm{g} /$ pot, $\mathrm{M}_{2}=$ mikoriza $20 \mathrm{~g} /$ pot, dan $\mathrm{M}_{3}=$ mikoriza $30 \mathrm{~g} /$ pot). Percobaan dilakukan dengan 3 kali ulangan sehingga terdiri atas $4 \times 4 \times 3$ $=48$ unit percobaan.

\section{Persiapan Tanah dan Pupuk}

Tanah yang digunakan diambil secara komposit dari kedalaman 0-20 cm kemudian dibersihkan dari sisa tanaman, batu dan kerikil. Untuk mendapatkan agregat tanah yang homogen terlebih dahulu tanah dikering udarakan, selanjutnya diayak dengan ayakan dari kawat dengan ukuran lubang berdiameter $2 \mathrm{~mm}$. Pupuk kandang sapi yang sudah matang didapat dari kandang peternakan sapi Bali perbibitan yang diberi pakan utama hijauan dan limbah sagu terfermentasi. Pupuk kandang tersebut dibersihkan dari sisa-sisa pakan dan benda-benda lain kemudian dihomogenkan, dikeringkan, dan ditimbang sesuai perlakuan pemupukan. Pupuk hayati mikoriza didapat dari koleksi Laboratorium taksonomi tumbuhan (Mikologi), Jurusan Biologi, FMIPA, Universitas Udayana.

\section{Persiapan Media Tanam dan Bibit}

Sebanyak $4 \mathrm{~kg}$ tanah kering udara yang lolos ayakan dengan lubang berdiameter $2 \mathrm{~mm}$ dimasukkan ke dalam pot plastik berdiameter $20 \mathrm{~cm}$, kemudian tiaptiap pot diberi pupuk kandang sapi sesuai perlakuan, dan selanjutnya diberi label. Bibit kacang pinto (Arachis pintoi) yang digunakan dalam penelitian ini didapat dari lahan kebun tanaman pakan milik petani berupa stek, dipilih batang kacang pinto dengan diameter batang yang homogeny selanjutnya dipotongpotong untuk mendapatkan stek yang masing-masing berisi 3 (tiga) ruas.

\section{Penanaman Bibit dan Inokulasi Mikoriza}

Setiap pot ditanami dengan 2 stek kacang pinto, apabila ada yang mati maka segera dilakukan penyulaman. Inokulasi mikoriza dilakukan pada saat penanaman bibit dengan memberikan mikoriza pada lubang tanam sesuai perlakuan.

\section{Pemeliharaan dan Pengamatan}

Pemeliharaan yang dilakukan adalah penyiraman setiap hari pada volume $100 \%$ kapasitas lapang, serta pengendalian hama dan penyakit bila diperlukan. Pengamatan terhadap peubah produksi dan karakteristik dilakukan setelah panen.

\section{Pemanenan}

Panen dilakukan pada saat tanaman berumur 12 minggu setelah tanam dengan cara memotong tanaman diatas permukaan tanah kemudian memisahkan antara batang, daun, dan bunga. Setiap bagianbagian tersebut ditimbang untuk mengetahui berat segarnya, kemudian dimasukkan ke dalam amplop untuk selanjutnya dikeringkan dengan oven pada suhu $70-80^{\circ} \mathrm{C}$ selama 48 jam atau sampai mencapai berat konstan untuk mendapatkan berat keringnya. Pengukuran luas daun dilakukan dengan mengambil beberapa sampel daun secara acak, ditimbang beratnya, dan diukur luasnya denganLeaf Area meter. Akar tanaman dibersihkan dengan air secara sangat hati-hati agar tidak merusak bintil akar yang ada pada akar tersebut, kemudian dihitung jumlah bintil akar yang ada pada setiap unit percobaan.

\section{Analisis Data}

Data yang diperoleh dianalisis dengan analisis sidik ragam. Apabila diantara nilai rata-rata perlakuan menunjukkan perbedaan yang nyata, maka analisis dilanjutkan dengan uji jarak berganda Duncan (ProgramSPSS).

\section{HASIL DANPEMBAHASAN}

Hasil analisis sidik ragam menunjukkan bahwa interaksi antara perlakuan pupuk hayati mikoriza dengan pupuk kandang sapi berpengaruh nyata $(\mathrm{P}<0,05)$ pada peubah kolonisasi akar kacang pinto. Perlakuan pupuk kandang sapi secara nyata $(\mathrm{P}<0.05)$ meningkatkan berat kering daun, batang, tajuk, akar dan jumlah bintil akar kacang pinto. Perlakuan pupuk hayati mikoriza berpengaruh nyata $(\mathrm{P}<0,05)$ terhadap kolonisasi akar kacang pinto.

Pemberian pupuk kandang sapi meningkatkan secara nyata $(\mathrm{P}<0,05)$ berat kering daun dan berat kering batang kacang pinto (Tabel 1), Hal ini disebabkan oleh kemampuan pupuk kandang dalam menambah hara, memperbaiki sifat-fisik, kimia, dan biologi tanah (Hartatik dan Widowati, 2006). Nilai pupuk kandang tidak saja ditentukan oleh kandungan nitrogen, asam fosfat, dan kalium saja, tetapi juga mengandung hamper semua unsure hara makro dan mikro yang dibutuhkan tanaman serta berperan dalam memelihara keseimbangan hara dalam tanah. Disamping itu, pupuk kandang yang digunakan adalah pupuk kandang sapi yang dihasilkan oleh sapi yang diberi pakan limbah sagu terfermentasi sehingga mikroba yang digunakan untuk fermentasi pakan masih ada saat sisa pakan keluar berupa feses, dan masih aktif ketika diaplikasikan ke dalam media tanam.

Berat kering tajuk kacang pinto yang diberi pupuk kandang sapi nyata lebih tinggi dibandingkan tanpa pemberian (Tabel 2), dan terus meningkat dengan meningkatnya dosis pupuk. Peningkatan berat kering tajuk terkait dengan peningkatan berat kering daun 
Tabel 1. Berat Kering Daun dan Batang Kacang Pinto (Arachis pintoi) yang Diberi Pupuk Kandang Sapi dan Mikoriza

\begin{tabular}{|c|c|c|c|c|c|c|c|}
\hline \multirow[b]{2}{*}{ Peubah } & \multirow{2}{*}{$\begin{array}{c}\text { Dosis } \\
\text { Pupuk } \\
\text { Kandang } \\
\text { Sapi }\end{array}$} & \multicolumn{4}{|c|}{ Dosis Mikoriza2) } & \multirow[b]{2}{*}{ Rataan } & \multirow[b]{2}{*}{$\mathrm{SEM}^{3}$} \\
\hline & & MO & M1 & M2 & M3 & & \\
\hline \multirow{5}{*}{$\begin{array}{l}\text { Berat Kering } \\
\text { Daun (g) }\end{array}$} & So & 1.23 & 1.43 & 0.47 & 1.40 & $1.13^{\mathrm{B} 1)}$ & \multirow{5}{*}{0.14} \\
\hline & S1 & 1.77 & 1.70 & 1.60 & 1.53 & $1.65^{\mathrm{A}}$ & \\
\hline & S2 & 1.70 & 2.07 & 1.93 & 1.67 & $1.84^{\mathrm{A}}$ & \\
\hline & S3 & 1.90 & 1.60 & 2.07 & 1.80 & $1.84^{\mathrm{A}}$ & \\
\hline & Rataan & $1.65^{\mathrm{A}}$ & $1.70^{\mathrm{A}}$ & $1.52^{\mathrm{A}}$ & $1.60^{\mathrm{A}}$ & & \\
\hline \multirow{5}{*}{$\begin{array}{l}\text { Berat Kering } \\
\text { Batang }(\mathrm{g})\end{array}$} & so & 0.53 & 0.67 & 0.47 & 0.60 & $0.57^{C}$ & \multirow{5}{*}{0.73} \\
\hline & S1 & 0.60 & 0.63 & 0.67 & 0.60 & $0.63^{B C}$ & \\
\hline & S2 & 0.70 & 0.83 & 0.70 & 0.70 & $0.73^{A B}$ & \\
\hline & S3 & 0.90 & 0.67 & 0.93 & 0.80 & $0.83^{\mathrm{A}}$ & \\
\hline & Rataan & $0.68^{\mathrm{A}}$ & $0.70^{\mathrm{A}}$ & $0.69^{A}$ & $0.68^{\mathrm{A}}$ & & \\
\hline
\end{tabular}

Keterangan

1) Nilai dengan huruf kapital berbeda pada kolom atau baris yang sama berbeda nyata $(P<0,05)$

2) $\mathrm{M} 0=$ tanpa mikoriza, $\mathrm{M} 1$ = mikoriza $10 \mathrm{~g} /$ pot, $\mathrm{M} 2=$ mikoriza $20 \mathrm{~g} /$ pot, $\mathrm{M} 3=$ mikoriza $30 \mathrm{~g} /$ pot

3) Standard Error of the Treatment Means

dan batangnya (Tabel1), yang disebabkan oleh kemampuan pupuk kandang sapi memperbaiki sifatfisik, kimia dan biologi tanah (Hartatik dan Widowati, 2006) sehingga dapat mendukung tanaman untuk meningkatkan produksinya.

Perlakuan pupuk kandang sapi dan mikoriza berpengaruh tidak nyata terhadap Nisbah daun/batang dan nisbah tajuk/akar tanaman kacang pinto (Tabel 3). Ini berarti tidak berpengaruh terhadap kualitas hijauan yang dihasilkan karena nisbah daun/batang merupakan salah satu indicator kualitas hijauan. Hal ini terjadi karena peningkatan berat kering daun diikuti dengan peningkatan berat kering batangnya.

Tabel 2. Berat Kering Tajuk dan Akar Kacang Pinto (Arachis pintoi) yang Diberi Pupuk Kandang Sapi dan Mikoriza

\begin{tabular}{|c|c|c|c|c|c|c|c|}
\hline \multirow[b]{2}{*}{ Peubah } & \multirow{2}{*}{$\begin{array}{c}\text { Dosis } \\
\text { Pupuk } \\
\text { Kandang } \\
\text { Sapi }\end{array}$} & \multicolumn{4}{|c|}{ Dosis Mikoriza2) } & \multirow[b]{2}{*}{ Rataan } & \multirow[b]{2}{*}{$\mathrm{SEM}^{3}$} \\
\hline & & Mo & M1 & M2 & M3 & & \\
\hline \multirow{5}{*}{$\begin{array}{l}\text { Berat Kering } \\
\text { Tajuk (g) }\end{array}$} & So & 1.77 & 2.10 & 1.80 & 2.00 & $1.92^{\mathrm{C} 1)}$ & \multirow{5}{*}{0.18} \\
\hline & S1 & 2.37 & 2.33 & 2.27 & 2.13 & $2.28^{\mathrm{BC}}$ & \\
\hline & S2 & 2.40 & 2.90 & 2.63 & 2.37 & $2 . .58^{A B}$ & \\
\hline & S3 & 2.80 & 2.27 & 3.00 & 2.60 & $2.67^{\mathrm{A}}$ & \\
\hline & Rataan & $2.33^{\mathrm{A}}$ & $2.40^{\mathrm{A}}$ & $2.43^{\mathrm{A}}$ & $2.28^{\mathrm{A}}$ & & \\
\hline \multirow{5}{*}{$\begin{array}{l}\text { Berat Kering } \\
\text { Akar }(\mathrm{g})\end{array}$} & so & 1.53 & 2.13 & 1.37 & 1.87 & $1.73^{\mathrm{B}}$ & \multirow{5}{*}{0.20} \\
\hline & S1 & 2.00 & 2.20 & 2.00 & 1.80 & $2.00^{\mathrm{AB}}$ & \\
\hline & S2 & 1.90 & 2.67 & 2.33 & 2.13 & $2.26^{\mathrm{A}}$ & \\
\hline & S3 & 2.50 & 2.00 & 3.00 & 2.20 & $2.43^{\mathrm{A}}$ & \\
\hline & Rataan & $1.98^{\mathrm{A}}$ & $2.25^{\mathrm{A}}$ & $2.18^{\mathrm{A}}$ & $2.00^{\mathrm{A}}$ & & \\
\hline
\end{tabular}

Keterangan

1) Nilai dengan huruf kapital berbeda pada kolom atau baris yang sama berbeda nyata $(P<0,05)$

2) $\mathrm{M0}=$ tanpa mikoriza, $\mathrm{M} 1=$ mikoriza10 $\mathrm{g} / \mathrm{pot}, \mathrm{M} 2$ = mikoriza $20 \mathrm{~g} / \mathrm{pot}, \mathrm{M} 3=$ mikoriza $30 \mathrm{~g} /$ pot

3) Standard Error of the Treatment Means

Perlakuan mikoriza mampu meningkatkan jumlah bintil akar kacang pinto pada perlakuan tanpa pupuk kandang sapi (So), tetapi tidak terjadi pada perlakuan kombinasi dengan pupuk kandang sapi (Tabel4). Hal ini berhubungan dengan kemampuan pupuk kandang sapi memperbaiki sifat biologi tanah sebagai pembawa mikroba yang bermanfaat untuk kesuburan tanah. Pupuk kandang sapi merupakan salah satu pupuk organic yaitu pupuk yang memiliki kandungan hara yang lengkap (Sumarsono dkk., 2005), dapat memperbaiki struktur tanah dan membantu perkembangan mikroorganisme tanah (Widjayanto dkk., 2001).

Tabel 3. Nisbah Daun/Batang dan nisbah Tajuk/akar Kacang Pinto (Arachispintoi) yang Diberi Pupuk Kandang Sapi dan Mikoriza

\begin{tabular}{|c|c|c|c|c|c|c|c|}
\hline \multirow[b]{2}{*}{ Peubah } & \multirow{2}{*}{$\begin{array}{c}\text { Dosis } \\
\text { Pupuk } \\
\text { Kandang } \\
\text { Sapi }\end{array}$} & \multicolumn{4}{|c|}{ Dosis Mikoriza2) } & \multirow[b]{2}{*}{ Rataan } & \multirow[b]{2}{*}{$\mathrm{SEM}^{3}$} \\
\hline & & MO & M1 & M2 & M3 & & \\
\hline \multirow{5}{*}{$\begin{array}{l}\text { Nisbah } \\
\text { Daun/Batang }\end{array}$} & So & 2.49 & 2.14 & 2.97 & 2.54 & $2.53^{\mathrm{A} 1)}$ & \multirow{5}{*}{0.25} \\
\hline & $\mathrm{S} 1$ & 2.97 & 2.70 & 2.57 & 2.57 & $2.70^{\mathrm{A}}$ & \\
\hline & $\mathrm{S} 2$ & 2.59 & 2.55 & 2.81 & 2.41 & $2 . .59^{A}$ & \\
\hline & S3 & 2.11 & 2.41 & 2.33 & 2.26 & $2.28^{\mathrm{A}}$ & \\
\hline & Rataan & $2.54^{\mathrm{A}}$ & $2.45^{\mathrm{A}}$ & $2.67^{A}$ & $2.44^{\mathrm{A}}$ & & \\
\hline \multirow{5}{*}{$\begin{array}{l}\text { Nisbah } \\
\text { Tajuk/Akar }\end{array}$} & So & 1.17 & 0.99 & 1.34 & 1.17 & $1.17^{\mathrm{A}}$ & \multirow{5}{*}{0.08} \\
\hline & $\mathrm{S} 1$ & 1.20 & 1.06 & 1.20 & 1.20 & $1.16^{\mathrm{A}}$ & \\
\hline & $\mathrm{S} 2$ & 1.27 & 1.13 & 1.13 & 1.12 & $1.16^{\mathrm{A}}$ & \\
\hline & S3 & 1.12 & 1.15 & 1.01 & 1.19 & $1.12^{\mathrm{A}}$ & \\
\hline & Rataan & $1.18^{\mathrm{A}}$ & $1.08^{\mathrm{A}}$ & $1.17^{\mathrm{A}}$ & $1.17^{\mathrm{A}}$ & & \\
\hline
\end{tabular}

Keterangan

1) Nilai dengan huruf kapital berbeda pada kolom atau baris yang sama berbeda nyata $(\mathrm{P}<0,05)$

2) $\mathrm{M} 0=$ tanpa mikoriza, $\mathrm{M} 1=$ mikoriza $10 \mathrm{~g} /$ pot, $\mathrm{M} 2=$ mikoriza $20 \mathrm{~g} /$ pot, $\mathrm{M} 3=$ mikoriza $30 \mathrm{~g} /$ pot

3) Standard Error of the Treatment Means

Tabel 4. Jumlah bintil akar dan Kolonisasi akar Kacang Pinto (Arachis pintoi) yang Diberi Pupuk Kandang Sapi dan Mikoriza

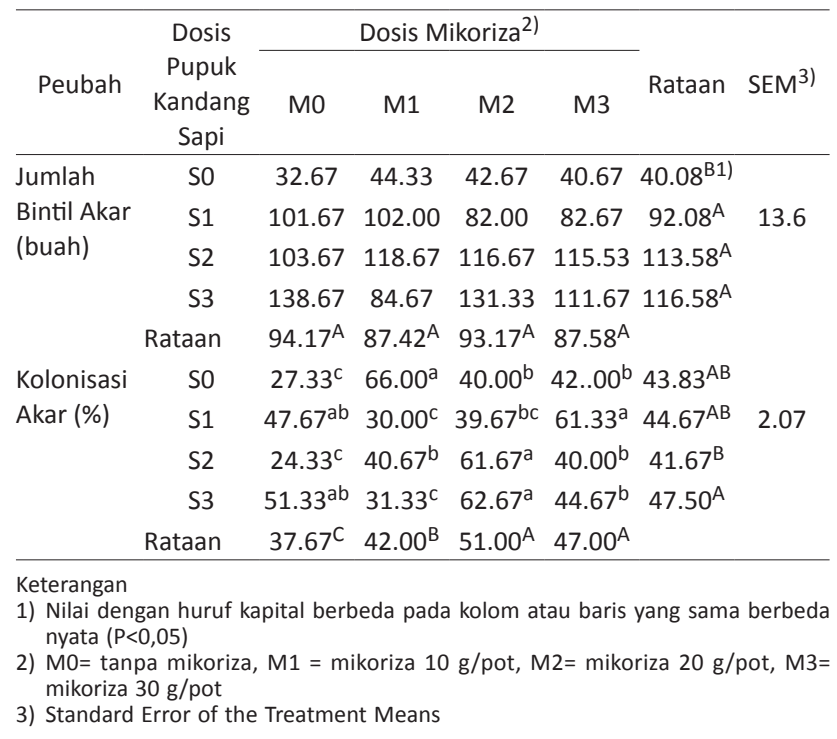

Kolonisasi akar tertinggi terjadi pada perlakuan mikoriza M1untuk perlakuan tanpa pupuk kandang sapi, perlakuan M3 untuk perlakuan pupuk kandang sapi S1,dan perlakuan M2 pada perlakuan pupuk kandang sapi S2 dan S3 (Tabel 4). Hal ini terjadi 
berkaitan dengan adanya persaingan dengan mikroba yang berasal dari pupuk kandang sapi dan kemampuan pupuk kandang sapi sebagai penyedia faktor tumbuh untuk mikroba tanah dan tanaman. Pupuk kandang selain mengandung unsur-unsur makro (Nitrogen, Fosfor, Kalium, Kalsium, Magnesium, dan Belerang) juga mengandung unsur-unsur mikro (Besi, Mangan, Boron, Tembaga, Seng, Klor dan Molibdinum) yang kesemuanya membentuk pupuk, menyediakan unsur-unsur atau zat-zat makanan bagi kepentingan pertumbuhan dan perkembangan tanaman (Sutedjo,1999).

\section{KESIMPULAN}

Berdasarkan hasil penelitian dapat disimpulkan bahwa interaksi antara perlakuan pupuk hayati mikoriza dengan pupuk kandang sapi berpengaruh pada peubah kolonisasi akar, perlakuan pupuk kandang sapidosis 20 ton/ha meningkatkan berat kering daun, batang,tajuk, akardan jumlah bintil akar sama dengan dosis 30 ton/ha, dan perlakuan pupuk hayati mikoriza dosis $20 \mathrm{~g} /$ pot menghasilkan kolonisasi akar paling tinggi.

\section{REFERENSI}

Abdullah, L. Panca Dewi, M.H.K., Soedarmadi, H. 2005. Reposisi tanaman pakan dalam kurikulum fakultas peternakan. Prosiding Lokakarya Nasional Tanaman Pakan Ternak; Bogor,
16 September 2005. Pusat Penelitian dan Pengembangan Peternakan. Badan Penelitian dan Pengembangan Pertanian. Hlm 11-17.

Ferguson, J.E and D.S. Loch. 1999. Arachis pintoi in Australia and Latin America. In Loch DS and JE Ferguson, editor. Forage seed Production. Tropica land Subtropical Species Volume 2. Oxon.UK.CABI Publishing. Hlm 427-434.

Hartatik W.dan L.R. Widowati. 2006. Pupuk Kandang. Balai Besar Litbang Sumber daya Lahan Pertanian Badan Penelitian dan Pengembangan Pertanian

Sirait, J., S.P.Ginting dan A.Tarigan. 2005. Karakterisasi morfologi dan produksi legume pada tiga taraf naungan di dua agroekosistem. Pros. Lokakarya Nasional tanaman Pakan Ternak Bogor, 16 September 2005.

Sugito, Y., 1999. Ekologi Tanaman: Pengaruh Factor Lingkungan Terhadap Pertumbuhan Tanaman dan Beberapa aspeknya, UB Press. Malang.

Sumarsono, S. Anwar dan S. Budiyanto. 2005. Peranan Pupuk Organik untuk Keberhasilan Pertumbuhan Tanaman Pakan Rumput Poliploid pada Tanah Masam dan Salin. Laporan Penelitian.Fakultas Peternakan Universitas Diponegoro, Semarang.

Sutedjo, M M. 1999. Pupuk dan Cara Pemupukan. Penerbit Rineka Cipta, Jakarta.

Widjajanto, D.W., Honmura, T., Matsushita, K., and Miyauchi, N. 2001.Studies on the release N from water hyacinth in corporate into soil-crop systems using 15 N-labeling techniques. Pak. J. Biol.Sci.,4 (9):1075-1077 